Economics Development Analysis Journal 7(3)(2018)

\title{
Analisis Faktor Produksi Terhadap Daya Saing Batik Semarangan
}

\author{
Susanti Lasmaria Purba ${ }^{1 凶}$, P. Eko Prasetyo ${ }^{2}$ \\ Jurusan Ekonomi Pembangunan, Fakultas Ekonomi, Universitas Negeri Semarang
}

\begin{tabular}{l}
\hline Info Artikel \\
Sejarah Artikel: \\
Diterima April 2018 \\
Disetujui Juni 2018 \\
Dipublikasikan Agustus \\
2018
\end{tabular}

Keywords:

Batik, human resources, raw materials, capital, competitiveness

\begin{abstract}
Abstrak
Kota semarang salah satu penghasil batik yang berkualitas namun belum dikenal banyak masyarakat indonesia. Dampak kurangnya faktor produksi mengakibatkan daya saing Batik Semarang kurang berkembang atau kurang dikenal banyak masyarakat. Penelitian ini mengkaji dampak kurangnya faktor produksi terhadap daya saing. Tujuan penelitian ini untuk menganalisis dampak kurangnya faktor produksi terhadap daya saing dan bagaimana pengaruh faktor produksi terhadap daya saing. Populasi penelitian ini sebanyak 36 industri Batik Semarangan. Analisis data digunakan analisis deskriptif, analisis SWOT dan analisis regresi. Hasil penelitian ini menganalisis dampak kurangnya faktor produksi terhadap daya saing yang menunjukkan bahwah diperlukan strategi yang sesuai untuk pengembangan daya saing batik Semarangan untuk mengoptimalkan pengelolahan produksi batik semarangan dan juga memperluas persaingan batik di daerah lain. Pengaruh signifikan faktor produksi SDM terhadap daya saing, faktor produksi Bahan baku ada pengaruh signifikan terhadap daya saing dan faktor produksi modal tidak ada pengaruh tidak signifikan terhadap daya saing. Saran yang diberikan dari penelitian ini yaitu para pembatik harus mempertahankan kualitas produk batik dan meningkatkan kualitas tenga kerja. Pemilik usaha seharusnya lebih banyak mengikuti pameran-pameran dari pemerintah dan instansi lainya terutama pameran yang di luar Kota Semarang agar Batik Semarangan dapat dikenal masyarakat luar Kota Semarang. .
\end{abstract}

\begin{abstract}
The impact of the lack of competitiveness of production factors resulted a less developed or less known of Batik Semarang to many people. This study examines the impact of the lack of production factors on competitiveness. The purpose of this study is to analyze the impact of the lack of production factors on competitiveness andhow the influence of production factors on competitiveness. The population of this study were 36 BatikSemarangan industries. Analysis is used descriptive analysis, SWOT analysis and regression analysis. Theresulsofthisstudy are to analyze the impact of the lack of production factors on competitiveness that shows that required an appropriate strategy for the development of competitiveness Batik Semarangan to optimize management production Batik Semarangan and also expanding batik competition in other areas. Significant influence of human resources production factors on the competitiveness, there is a significant effect ofrawmaterialsproduction factors on the competitiveness and there is no significant influence of production factors of capital on the competitiveness. The advice given from this study is the batik maker must maintain the quality of theirproduct and improve the quality of worker. Business owners should attend a lot of exhibitions under governmentsbelt and other agencies, especially the exhibition outside Semarang, in order for Batik Semarangan canbeknownby the people outside Semarang.
\end{abstract}

(C) 2018 Universitas Negeri Semarang

\footnotetext{
凶Alamat korespondensi:

Ruang Jurnal Gedung L FE UNNES, Sekaran Gunungpati

Semarang, 50229, Indonesia

E-mail: susantilasmaria@gmail.com
} ISSN 2252-6965 


\section{PENDAHULUAN}

Industri adalah usaha untuk memproduksi barang-barang jadi, dari bahan baku atau bahan mentah melalui suatu proses penggarapan dalam jumlah besar sehingga barang-barang itu bisa saja diperoleh dengan harga satuan yang serendah mungkin tetapi tetap dengan mutu setinggi mungkin. Perkembangan Ekonomi lokal dikota semarang cukup berkembang pesat jumlahnya. Karena kota semarang merupakan pusat ibu kota jawa tengah yang memiliki beberapa hasil produksi yang mempunyai nilai unggulan yang harus dikembangkan. Potensi ekonomi lokal ini apabila tidak ada pembinaan secara optimal, maka akan menjadi kendala dikemudian hari, kondisi pengembangan ekonomi di Era Global dan masyarakat Ekonomi Asia yang sudah mulai berjalan dan sangat terasa kondisi sekarang.

Salah satu industri yang ada di Indonesia adalah industri Batik, batik sudah dikenal banyak masyarakat indonesia bahkan luar negeri sudah mengenal batik indonesia seperti batik Pekalongan, batik Yogyakarta, batik Solo. Batik sudah menjadi trend dikalangan masyarakat, hal ini dibuktikan dengan batik disetiap kota memiliki batik. Hal ini juga tidak terlepas dari peran pemerintah yang menggerakan dan mendukung. Di semarang pengunaan batik misalnya diperkantoran pemerintah setiap hari jumat para pegawai menggunakan batik dan hal ini mendorong masyarakat untuk lebih mengemari batik. Nnamun masyarakat masih kurang mengenali batik yang mereka gunakan dan kebanyakan masyarakat lebih menggunakan batik Pekalongan, batik Yogyakarta karena harganya lebih murah dan sudah dikenal banyak masyarakat indonesia bahkan kota semarang masih banyak menggunakan batik lain padahal semarang memiliki batik sendiri yang motifnya tidak kalah saing dengan batik lain, peneliti juga melakukan surve kelapangan seperti bertanya pada masyarakat semarang apakah mereka sudah mengenali batik semarang dan hasil surve beberapa masyarakat semarang kebanyakan tidak mengenal batik semarangan.

Batik Semarangan merupakan warisan budaya yang khas dan unik sekaligus menjadi identitas budaya Kota Semarang. Batik semarangan dapat didefinisikan sebagai hasil kerajinan berupa kain bermotif Khas Semarang yang harus dikerjakan melalui tiga proses produksi, yaitu pemalaman (pencantingan), pencelupan (pewarnaan) dan pelorotan (melorotkan malam), dan dikelolah oleh masyarakat IKM kota semarang. Batik Semarangan sebenarnya sudah ada sejak awal perempatan abad ke-20, kemudian mengalami mati suri sejak masuknya tentara jepang kesemarang pada tahun 1942 .

Tahun 2005 pemerintah Kota Semarang berusaha menghidupkan kembali industri batiknya, hingga pada tahun 2006, industri batik semarangan yang sudah lama stagman dalam usaha mengalami perkembangan. Potensi yang ada pada Batik Semarangan ini perlu dikembangkan karena dapat memperkuat kepribadian bangsa, selain itu jika dilihat dari sisi ekonomi potensi tersebut ditunjukkan oleh munculnya IKM-IKM yang berkecipung pada Batik Semarangan dan berorientasi pada keuntungan serta kemajuan usaha. Dalam pembangunan Ekonomi, IKM selalu digambarkan sebagai sektor yang mempunyai peran penting karena mampu meengurangi jumlah pengangguran atau dapat disebut IKM tersebut dapat menyerap tenaga kerja.

Pengrajin batik tidak hanya dikota semarang namun diseluruh Wilayah Indonesia dengan beraneka ragam motif dan desain yang sesuaikan dengan kultur budaya yang ada di wilayah tersebut karena usaha batik dinilai mempunyai prospek bisnis yang menguntungkan maka industri-industri batik di era sekarang banyak dilakukan oleh kaum kaum remaja dan orang tua.

Peran pemerintah dalam mengembangkan industri batik semarangan sangat penting seperti yang dikatakan (Indra Hanafi, SE 2015) selaku pegawai di DISPERINDAG divisi Industri mengatakan bahwa Dinas Perindustrian dan Perdanganagan melakukan pelatihan kerajinan Batik selain melakukan pelatihan Dinas Perindustrian dan perdagangan membuat klaster klaster pada tahun 2010 namun klaster batik Kota Semarang berdiri pada tahun 2012 dari 
Susanti Lasmaria Purba \& P. Eko Prasetyo/ Economics Development Analysis Journal 7 (3) (2018)

pelatihan tersebut masyarakat bisa mendirikan IKM batik sendiri.

Profil Industri Kecil dan Menengah Batik di Kota Semarangan Tahun 2009-2013, bahwa terdapat perkembangan pada industri batik di Kota Semarang. Hal tersebut ditunjukkan oleh bertambahnya unit usaha batik serta bertambahnya penyerapan tenaga kerja yang ada pada IKM Batik. Karena itu potensi Batik Semarangan yang telah ada ini perlu dikembangkan lagi secara konsisten dan berkelanjutan.

Tabel 1. Deskripsi Industri Kecil Batik di Kota Semarangan Tahun 2009-2013

\begin{tabular}{lllll}
\hline Tahun & $\begin{array}{l}\text { Jumlah } \\
\text { Usaha }\end{array}$ & $\begin{array}{c}\text { Unit } \\
\begin{array}{l}\text { Nilai Produksi } \\
(\mathrm{Rp} \mathrm{000)}\end{array}\end{array}$ & $\begin{array}{l}\text { Nilai Investasi } \\
(\mathrm{Rp} \mathrm{000)}\end{array}$ & $\begin{array}{l}\text { Tenaga } \\
\text { kerja }\end{array}$ \\
\hline 2009 & 37 & 1.445 .000 & 1.758 .000 & 178 \\
2010 & 38 & 1.945 .000 & 1.820 .000 & 183 \\
2011 & 39 & 1.704 .000 & 1.517 .000 & 190 \\
2012 & 40 & 1.822 .000 & 1516.000 & 200 \\
2013 & 44 & 1.933 .000 & 1.459 .000 & 201 \\
\hline
\end{tabular}

Sumber : Dinasperindag Kota Semarang

Dari tabel 1 diatas jelaslah bahwa peran Dinas perindustrian dan Perdagangan Kota Semarang sebagai fasilitator yang memberikan kontribusi pada masyarakat IKM Batik dalam mengembangkan Potensi Batik Semarangan dengan cara mengoptimalisasikan pembentukan ikm klaster Batik Semarangan. Tujuan program pelatihan klaster batik Semarangan adalah dengan adanya pelatihan ini IKM Batik Semarangan semakin Bertambah dan batik semarangan makin banyak dikenal oleh masyarakat selain itu munculnya ide ide kreatif dari pelatihan pembuat Batik tersebut dapat meningkatkan potensi Batik Semarangan.

Namun yang terjadi dilapangan masyarakat pembatik Semarangan yang telah di surve peneliti di kampung Batik yaitu bahwa batik semarangan belum berkembang karna masih banyak permasalahan yang dialami oleh masyarakat pembatik semarangan seperti :

Sumber daya manusia ( SDM) , SDM yang masih kurang pandai bahkan ada sebagian pembatik ini tidak memiliki tenaga kerja karena sangat sulit mencari tenaga kerja yang pandai dalam membatik semarangan. Cara pembatik yang tidak memiliki tenaga kerja ini memproduksi yang dilakukan ialah pembatik hanya membuat motifnya yang melakukan proses selanjutnya biasanya pembatik mrngirim motifnya ke pekalongan.
Bahan baku yang tidak lengkap dikota semarang hasil surve mengatakan bahwa bahan baku untuk batik itu belum lengkap, jadi pembatik biasanya membeli bahan baku dari pekalongan.

Daya saing batik semarangan masih sekitar semarang dan jawa tengah saja.

Harga batik Semarang yang masih tinggi sehingga masyarakat tidak mau membeli Batik semarangan, masyarakat lebih memilih membeli batik perinting yang harganya jauh lebih murah sehingga pembatik tidak hanya membatik batik semarangan saja namun juga membatik perinting karena batik perinting dapat meningkatkan jumlah produksinya dibandingkan batik Semarang.

\section{METODE PENELITIAN}

Penelitian ini merupakan jenis penelitian dengan metode kuantitatif. Analisis data digunakan untuk mengolah data yang diperoleh pada saat melakukan penelitian. Alat analisis yang digunakan dalam penelitian ini ialah deskriptif, Analisis SWOT dalam Hermanto (2016) dan Regresi. Analisis SWOT digunakan untuk mengetahui strategi pengembangan daya saing Batik Semarangan. Analisis Regresi digunakan untuk mengetahui bagaimana pengaruh sumber daya manusia, bahan baku dan 
modal terhadap daya saing. Jumlah populasi yang diambil peneliti 36 usaha industri Batik semarangan di Kota Semarang.

\section{HASIL DAN PEMB AHASAN}

Sumber Daya Manusia (SDM), Usaha batik semarangan memiliki jumlah tenaga kerja rata rata antara 2 sampai 10 tenaga kerja saja karena usaha batik semarangan ini masih industri rumahan jadi jumlah tenaga kerjanya masih sedikit belum seperti industri yang sudah besar dan nama hasil produksinya sudah dikenal oleh banyak masyarakat terutama masyarakat indonesia.

Asal tenaga kerja yang dimiliki oleh para pengusaha batik semarangan ini juga masih banyak dari luar kota semarangan dan tenaga kerja yang dari keluarga pemilik usaha tersebut, salah satu masalah yang dihadapi oleh para pengusaha batik ini ialah asal tenaga kerjanya soalnya pemili usaha sangat sulit untuk mendapatkan tenaga kerja yang sudah terlatih dalam membantik makanya kebanyakan asal tenaga kerja dari luar kota semarang.

Status tenaga kerja yang dimiliki oleh pengusaha batik semarangan ini juga ada pegawai tetap dan ada juga pegawai musiman. Upah tenaga kerjanya juga berdasarkan mingguan, dan ada juga borongan karana pembuatan batik tidak bisa ditarget berapa yang akan diproduksi ,selain itu pembuatan batik juga masih tradisional jadi sulit untuk menargetkan hasil produksinya, tenaga kerja biasanya membuat batik menurut pesanan. Jika tidak ada pesanan tenaga kerja batik semarangan biasanya tidak bekerja namun pemilik usaha biasanya membatik untuk batik yang akan mereka jual ditokoh milik pengusaha.

Jam kerja yang dipakai oleh tenaga kerja untuk membuat batik perharinya mulai dari jam 08:00 - 16:00 WIB atau kurang lebih 8 jam / harinya. Dalam melaksanakan pekerjaan tidak harus ditempat pemilik usaha melainkan bisa dibawa ke rumahnya. Pekerjaan yang diteruskan dirumah seperti membuat motif, selain dikarenakan pekerjaanya seorang ibu rumah tangga, tempat pemilik usaha juga tidak terlalu berguna menampung semua pekerja. Kebanyakan pemilik usaha hanya menggunakan rumah atau tempat usaha hanya sebagai proses dari pembuatan batik tulis. Para pekerja yang telah selesai membuat motif batik di rumah masing-masing akan mengantarkan hasil motif batiknya kepemilik usaha dan langsung mendapatkan upah.

Pembagian pekerjaan tenaga kerja di beberapa usaha batik semarangan ada yaitu menurut keahlian dan kemampuan tenaga kerja. Tenaga kerja juga menerima pelatihan membatik dari pemilik usaha. Biasanya pelatihan seperti pembukuan, promosi yang dari pemerintah diterima oleh pemilik usaha.

Dampak kuranya Sumber daya manusia terhadap daya saing ialah daya saing batik semarang tidak akan berkembang, terutama jika sumber daya manusia yang dimiliki pengusaha tidak memiliki keterampilan ataupun kualitas dalam membatik. Sulitnya memperoleh sumber daya manusia atau tenaga kerja ini akan berdampak jumlah produksi batik semarangan akan menurun dan pemasaran atau daya saingnya tidak banyak sehingga barang yang diproduksi sedikit itu hanya dapat dijual dikota semarang saja.

Bahan baku yang digunakan oleh usaha batik semarangan ialah kain, obat pewarna, lilin batik dan bahan bakar dan bahan banku lainnya. Sumber bahan baku yang dimiliki oleh pengusaha batik semarangan ini kebanyakan dari pekalongan. Salah satu kendala yang dihadapi para pengusaha batik yaitu memperoleh bahan baku karena bahan baku yang mereka miliki sangat mahal dan untuk memperolehnya membutuhkan waktu yang lama karena diperoleh dari luar kota semarang. Jauhnya untuk memperoleh bahan baku untuk membuat batik semarangan dibutuhkan biaya atau ongkos kirim akibatnya batik semarangan sangat mahal. Tetapi para pemilik batik semarangan sudah terbiasa dengan hal tersebut. Kualitas bahan baku pembuatan batik semarangan harus kualitas yang bagus setelah peneliti menanyakan kepada pengusaha pemilik usaha biasanya membeli bahan baku dari pekalongan dan kualitas bahan bakunya harus yang bagus karena 
kualitas bahan tersebutlah yang akan menjadi keunggulan batik semarangan.

Dampak kuranya bahan baku pembuatan batik semarangan terhadap daya saing ialah karena kurangnya bahan baku pembuatan batik semarangan menjadikan sulitnya untuk memproduksi batik, jika ada pesanan yang banyak biasanya pengusaha harus terlebih dahulu memesan bahan bakunya kepekalongan. Tidak tersedianya penjual bahan baku pembuatan batik semarangan di kota semarang menjadikan sulitnya memproduksi batik secara cepat akibatya daya saing batik semarangan tidak berkembang, karena pembatik selalu hanya menunggu pesanan pembeli batik saja baru memproduksi batik.

Modal Usaha, dari 36 populasi usaha batik dikota semarang yang diambil peneliti ada 26 usaha batik semarangan memiliki modal awal dari modal pribadi, sisanya 14 usaha batik semarangan sumber modalnya dari pinjaman dan pribadi.

Daya Saing, Produk batik yang dihasilkan oleh para pembatik semarangan kebanyakan Batik Tulis dan Batik Cap. Pemasaran Batik semarangan masih kebanyakan di lokal saja dikota semarang dan pembeli batik semarangan kebanyakan dari pemerintahan kota semarang dan anak anak sekolah saja selain itu masyarakat lain belum mengenal batik semarangan seperti yang pernah ditanyakan peneliti pada masyarat tentang batik semarangan ,kebanyakan masyarakat belum mengenal batik semarangan dan motif yang dimiliki batik semarangan yang masyarakat ketahui ialah motif tugu muda dak laweng sewu saja padahal banyak motif-motif lain yang dihasilkan oleh para pembatik semarangan dan tidak kalah saing dengan batik lain seperti batik pekalongan, solo dan yogyakarta.

Pengusaha juga memasarkan batiknya hanya mengikuti pameran saja dan berjualan dirumah saja.Pengusaha batik semarangan juga tidak hanya menjual batik semarangan saja mereka juga menjual dan membuat batik pekalongan, solo dan yogyakarta dan kebanyakan yang mereka jual batik pekalongan karena batik pekalongan sudah terkenal dan sudah banyak masyarakat yang mengenalnya karena dengan menjual batik pekalongan dapat menambah pendapatan pemilik usaha juga. Selain itu harganya juga lebih murah dari batik semarangan. Keunggulan batik semarangan ialah kualitas kain dan pewarnaan yang membuat beda dari batik lainnya. Dalam mengadapi persaingan para pemilik batik hanya mengikuti pasar saja dan pembuatan batiknya, pemilik batik tetap berusaha membuat motifmotif baru.

Analisis SWOT untuk pengembangan Daya saing, faktor-faktor yang mempengaruhi daya saing usaha batik semarangan antara lain terdapat pada lingkungan internal dan eksternal. Lingkungan internal merupakan cerminan kekuatan dan kelemahan dari usaha. Faktor internal dalam penelitian ini terdapat 5 variabel, yaitu tenaga kerja, bahan baku, modal, teknologi dan pemasara. Kelima variabel tersebut setealah dianalisis dan persentase yang cukup besar mempunyai pengaruh pada daya saing batik semarangan. Variabel-variabel tersebut yang kemudian menjadi kekuatan dan kelemahan untuk menentukan strategi yang dapat untuk mengetahui pengaruh daya saing batik semarangan.

Lingkungan eksternal merupakan kondisi diluar perusahaan yang dapat mempengaruhi perkembangan perusahaan dalam menjalankan usahanya. Menurut (Viljoen 1991:152 dalam Moeljadi 1998:28) lingkungan eksternal ini sering disebut sebagai eksternal Opportunities dan Treats (Glueck 1993 dalam Moeljadi (1998:28) menyebutkan lingkungan ini sebagai "Faktor-faktor luar perusahaan yang dapat menimbulkan peluang dan ancaman". Faktor eksternal diidentifikasi terdapat 3 variabel, dukungan pemerintah, pesaing, pangsa pasar. Semua variabel lingkungan eksternal tersebut dianalisis hasilnya yang mempunyai pengaruh dan dijadikan peluang dan ancaman daya saing batik semarangan:

1. Kekuatan usaha batik semarangan, penentuan faktor-faktor kekuatan dari lingkungan internal berdasarkan dari penelitian awal yaitu melalui memberi kuesioner dan wawancara dengan pemilik usaha batik 
semarangan. Kemudian dilakukan pengolahan data dengan cara menyusun ranking dan pembobotan dari data yang digabung antara data perwakilan usaha batik semarangan dan perwakilan dari dinas. Berdasarkan hasil yang diperoleh mengenai kekuatan dari usaha batik semarangan.

Usaha batik semarangan diperoleh dari aspek kekuatan dengan faktor indikator batik semarangan tetap menjaga kualitas batik Tulisnya dengan skor pembobotan sebesar 0,46. Hal tersebut pembutan Batik semarangan dibutuhkan waktu yang lama karena para pembatik lebih mementingkan kualitas batik tulisnya.

Kelemahan dari usaha batik semarangan adalah faktor indikator pemilik usaha menggunakan uang pribadi untuk modal usahanya memperoleh skor sebesar 0,32. Hal tersebut membuat para pembatik tidak mampu memproduksi batik semarangan. Maka perlu adanya sosialisasi cara meminjam dari bank atau instansi pemerintahan yang tidak rumit, agar dapat membantu permodalan usaha batik semarangan.

Penentuan faktor-faktor kekuatan dari lingkungan eksternal berdasarkan dari penelitian awal yaitu melalui kuesioner dan wawancara dengan pihal pemilik usaha batik semarangan. Menentukan faktor peluang dan ancaman terhadap usaha batik semarangan. Selanjutnya dilakukan pengolahan data dengan cara menyusun ranking dan pembobotan dari data yang digabungkan antara data yang diperoleh dari perwakilan pemilik usaha batik dan perwakilan dari dinas. Diperoleh hasil mengenai kekuatan dari usaha batik semarangan.

Peluang yang dimiliki oleh usaha batik adalah faktor indikator adalah adanya dukungan dari pemerintah (Bappeda, Disperindag dan dinas-dinas lain) diperoleh sebesar 0,46. Hasil tersebut menunjukkan bahwa pengusahapengusaha batik semarangan setuju dengan adanya dukungan dari pemirintah agar dapat mengembangkan usaha batik semarangan. Selain itu dengan adanya dukungan memakai hasil produksi batik semarangan sebagai seragam pemerintah dapat memperluas daya saing dan semakin banyak yang akan mengenal batik semarangan.

Ancaman usaha Batik semarangan, aktor indikator adanya pesaing produk batik semarangan dari luar kota semarang seperti batik pekalongan, solo yang memperoleh skor pembobotan sebesar 0,53 . Hal tersebut membuat masyarakat kurang mengenali batik semarang karena adanya batik lain seperti batik pekalongan yang sudah terkenal dan harganya juga lebih murah daibandingkan batik semarangan.

Dari dampak diatas menjadikan daya saing batik semarangan berkurang sehingga harus ada strategi internal dan eksternal yang akan dilakukan oleh pemilik usaha untuk mengembagkan daya saing batik semarangan.

Faktor strategi Internal aspek kekuatan dalam mengembangkan daya saing batik semarangan.Batik Semarang tetap menjaga Kualitas batik Tulisnya dengan mendapatkan skor sebesar 0,46. Aspek kelemahan dalam mengembangkan daya saing batik semarang ialah batik semarangan belum dikenal banyak masyarakat mendapatkan skor sebesar 0,19.

Faktor strategi Eksternal aspek peluang dalam mengembangkan daya saing batik semarangan Adanya dukungan dari pemerintah (bappeda,disperindag dan dinas-dinas lain) mendapatkan skor 0,46.Aspek ancaman dalam pengembangan daya saing batik semarangan Adanya pesaing produk batik semarangan dari luar kota semarang seperti batik pekalongan dan solo mendapatkan skor sebesar 0,53.

Strategi pengembangan daya saing batik semarangan yang harus dilakukan ialah mengoptimalkan pengelolahan produksi batik semarangan dan juga memperluas persaingan batik didaerah lain.

Pengaruh Sumber daya manusia terhadap daya saing batik semarangan, hasil penelitian menunjukkan bahwa secara koefisiensi diterminansi menunjukan bahwa adanya pengaruh signifikan antara sumber daya manusia dan daya saing. Berdasarkan hasil uji koefisien determinansi (R2), besarnya adjusted R Squeare sebesar 0,729. Angka tersebut menjelasnkan bahwa variabel daya saing mampu dijelaskan oleh variabel sumber daya manusia sebesar 
$72,9 \%$ dan sisanya sebesar $27,1 \%$ dipengaruhi oleh faktor-faktor lain yang tidak diteliti oleh peneliti. Hasil uji Simultan nilai F hitung sebesar 32,310 dengan signifikansi sebesar 0,000 yang lebih kecil dari 0,05 sehingga menunjukan bahwah terdapat pengaruh positif antara sumber daya manusia terhadap daya saing batik semarangan.

Hal ini mengandung makna bahwa sumber daya manusia sangatlah berpengaruh positif signifikan untuk daya saing batik semarangan karena sumber daya manusia dalam industri sangatlah berperan penting untuk pengembangan daya saing batik semarangan.Selain itu, berdasarkan hasil uji $\mathrm{t}$ besarnya sumber daya manusia 4,665. Hal ini berarti bahwa variabel sumber daya manusia memeberikan pengaruh besar terhadap daya saing batik semarangan.

Faktor sumber daya manusia berpengaruh positif signifikan terhadap daya saing dalam penelitian sesuai dengan teori Porter dalam kondisi faktur posisi negara dalam faktor produksi, seperti tenaga kerja terampil dan berkualitas perlu bersaing dalam suatu industri. Jumlah tenaga kerja harus mencukupi bukan saja dilihat dari ketersediaannya tetapi juga dari kualitas dan macam tenaga kerja itu sendiri (Soekartawi, 2003). Hasil dari penelitian ini didukung oleh temuan dari hasil penelitian Elfi eka Wanty (2006) dengan judul Analisis produksi Batik cap dari UMKM Batik Kota Pekalongan, menyatakan bahwa variabel Sumber daya manusia berpengaruh positif terhadap produksi.

Pengaruh bahan baku terhadap daya saing batik semarangan, hasil penelitian menunjukkan bahwa secara koefesien determinasi menunjukan bahwa adanya pengaruh signifikan antara Bahan baku dan daya saing. Berdasarkan hasil uji koefisien determinan (R2), besarnya adjusted $\mathrm{R}$ Squeare sebesar 0,729. Angka tersebut menjelasnkan bahwa variabel daya saing mampu dijelaskan oleh variabel Bahan Baku sebesar $72,9 \%$ dan sisanya sebesar $27,1 \%$ dipengaruhi oleh faktor-faktor lain yang tidak diteliti oleh peneliti. Hasil uji Simultan nilai F hitung sebesar 32,310 dengan signifikansi sebesar 0,000 yang lebih kecil dari 0,05 sehingga menunjukan bahwah terdapat pengaruh positif antara Bahan baku terhadap daya saing batik semarangan.

Hal ini mengandung makna bahwa bahan baku sangatlah berpengaruh besar terhadap daya saing karena bahan baku membuatan batik semarangan harus berkualitas karena ke unggulan dari batik semarang ialah kualitas bahanya, jika baha hasil produsi berkualitas maka produk batik semarangan dapat bersaing dengan batik lain. sehingga sangat mempengaruhi daya saing Selain itu, berdasarkan hasil uji t koefisien besarnya Bahan baku 3,733. Hal ini berarti bahwa variabel Bahan baku memeberikan pengaruh besar terhadap daya saing batik semarangan.

Hasil dari penelitian ini didukung oleh temuan dari hasil penelitian Elfi eka Wanty (2006) dengan judul Analisis produksi Batik cap dari UMKM Batik Kota Pekalongan, menyatakan bahwa variabel bahan baku berpengaruh positif terhadap produksi. Jika kualitas bahan baku baik maka produk yang dihasilkan berkualitas baik dengan demikian pembeli atau konsumen pasti tertarik pada batik semarangan dan daya saing akan meningkat. .

\section{SIMPULAN}

Simpulan dalam penelitian yaitu bahwa ada beberapa dampak kurangnya faktor produksi yang membuat daya saing tidak berkembang, yaitu sulitnya mendapatkan tenaga kerja yang berkualitas, harga bahan baku yang sangat mahal, bahan baku pembuatan batik belum tersedia di kota semarang, sehingga harus ada strategi yang dilakukan untuk mengembangkan daya saing batik semarangan.

Strategi yang harus dilakukan ialah mengoptimalkan pengelolahan produksi batik Semarangan. Pemilik usaha batik sebaiknya bekerjasama dengan dinas-dinas pemerintahan dengan baik agar dapat mengembangkan daya saing batik semarangan.

Sumber daya manusia memiliki pengaruh positif terhadap daya saing Batik semarangan. Artinya jika jumlah sumber daya manusia semakin meningkat atau jumlah tenaga kerja 
meningkat makan hasil produksii batik akan semakin banyak dan pemasaran batik semakin luas dapat meningkatkan daya saing.

Bahan Baku memiliki pengaruh positif terhadap daya saing Batik Semarangan. Artinya jika bahan baku pembuatan batik berkualitas dan dipercaya masyarakat akan meningkatkan daya saing.

Modal tidak berpengaruh positif terhadap daya saing. Artinya modal usaha yang digunakan para pembatik semarangan sebagian menggunakan modal pribadi dan sebagaian lagi pemilik usaha meminjam uang dari Dinas seperti dari Disperindag,UMKM dan lain-lain..

Produk batik dapat bersaing dengan batik lain, maka pemilik usaha batik harus lebih memperbanyak produksi batik dan memperluas pemasaran batik semarangan, Dinas UMKM, Disperindag dan dinas-dinas lain harus memperbanyak memberikan pelatihan pada pemilik usaha dan juga tenaga kerja pembuatan batik semarangan, sebaiknya pemerintah membuka koperasi penjualan bahan baku pembuatan batik di Kota Semarang agar para pemilik batik tidak membeli bahan baku keluar dari Kota Semarang, pemilik usaha seharusnya lebih banyak mengikuti pameran-pameran dari pemerintah yang dilaksanakan diluar kota seamarang agar masyarakat diluar Kota Semarang lebih mengenal batik semarangan.

\section{DAFTAR PUSTAKA}

Ahyari, Agus. 2005. Manajemen Produksi Edisi 4. Yogyakarta: BPFE
Ahyari, Agus. 2005. Manajemen Produksi Pengendalian Produksi Buku I Pengendalian Proses Pengendalian Bahan Baku Pengendalian Tenaga Kerja, Edisi 4, Yogyakarta : BPFE.

Bonita, Farah. 2013. Strategi Pengembangan Industri Kecil Kerajinan Batik Di Kota Semarang. Jurnal. Semarang : Universitas Negeri Semarang.

Daryanto, Aref dan Yundy Hafizrianda. 2010. Modelmodel Kuantitatif Untuk Perencanaan Pembangunan Ekonomi Daerah : Konsep Dan Aplikasinya. Bogor: IPB Press.

Gozali, I. 2006. Statistik non parametric dan aplikasi program SPSS.

Hidayati,Wahyu.2014. Analisis Pengembangan Usaha Pada UMKM Batik Semarangan di Kota Semarang,jurnal.

Hwy-chang moon dan dong sung cho fromadam smith to Michael poter evolusi teori daya saing.Jakarta:lembaga Penerbit selemba empat.

Mudrajad, Kuncoro.2007. Ekonomika Industri Indonesia. Yogyakarta:C.V Andi Offset.

Porter, Michael E.1990. The Competitive Advantage of Nations. New York. The Free Press

Prasetyo, P.Eko. 2009. Fundamenntal Makro Ekonomi. Yogyakarta:Beta Offset. .2010. Ekonomi Industri. Yogyakarta:Beta Offset.

Rangkuti, F. 1998. Analisis SWOT : Teknik Membedah Kasus Bisnis. Cetakan Ketiga. PT. Gramedia Pustaka Utama: Jakarta.

Wanty, Elfie Eka. 2006. Analisis Produksi Batik Cap dari UKM Batik Kota Pekalongan. Tesis. Fakultas Ekonomi Universitas Diponegoro. Semarang : Universitas Diponegoro. 